\title{
PENGARUH MODEL PEMBELAJARAN BERBASIS MASALAH TERHADAP HASIL BELAJAR SISWA PADA MATERI POKOK SUHU DAN KALOR KELAS X SEMESTER II SMA NEGERI 20 MEDAN T.P $2013 / 2014$
}

\author{
Nova Eunike Br Perangin-angin dan Henok Siagian \\ Jurusan Fisika FMIPA Universitas Negeri Medan \\ nova.eunike@yahoo.com
}

\begin{abstract}
ABSTRAK
Penelitian ini bertujuan untuk mengetahui pengaruh model pembelajaran berbasis masalah terhadap hasil belajar siswa kelas X semester II pada materi pokok suhu dan kalor SMA Negeri 20 Medan T.P 2013/2014. Jenis penelitian ini adalah quasi eksperimen. Populasi dalam penelitian adalah seluruh siswa kelas X Peminatan science yang terdiri dari 3 kelas. Pengambilan sampel dilakukan dengan cara cluster random sampling dengan mengambil 2 kelas yaitu kelas X-MS 1 sebagai kelas eksperimen yang berjumlah 33 orang dan kelas X-MS 2 sebagai kelas kontrol yang berjumlah 33 orang. Instrumen yang digunakan untuk mengetahui hasil belajar siswa adalah tes hasil belajar yang berbentuk essay test dengan jumlah 10 soal.

Berdasarkan hasil penelitian diperoleh nilai rata-rata pretes kelas eksperimen 43,69 dengan simpangan baku 7,8 dan nilai rata-rata kelas kontrol 42,78 dengan simpangan baku 8,5. Berdasarkan hasil uji beda nilai kedua kelas pada taraf signifikan $\alpha=0,05$ diperoleh thitung $=0,455$ dan $t_{\text {tabel }}=1,998$ maka kedua kelas memiliki kemampuan awal yang sama. Kemudian diberikan perlakuan yang berbeda, kelas eksperimen dengan model pembelajaran berbasis masalah dan kelas kontrol dengan pembelajaran konvensional. Setelah pembelajaran selesai diberikan, dilakukan postes dengan hasil rata-rata kelas eksperimen 75,06 dengan simpangan baku 8,587 dan kelas kontrol 67,818 dengan simpangan baku 7,69. Berdasarkan hasil uji t diperoleh $t_{\text {hitung }}=3,70$ dan $t_{\text {tabel }}=1,669$ yang berarti ada pengaruh yang signifikan terhadap penerapan model pembelajaran berbasis masalah terhadap hasil belajar siswa pada materi pokok suhu dan kalor kelas X SMA Negeri 20 Medan.
\end{abstract}

Kata Kunci : Model Pembelajaran Berbasis Masalah, Hasil belajar, Suhu dan Kalor

\section{PENDAHULUAN}

Kemajuan suatu bangsa sangat ditentukan oleh kualitas sumber daya manusia dimana kualitas sumber daya manusia tersebut bergantung pada kualitas pendidikan. Namun fakta yang terlihat di lapangan pada pembelajaran fisika masih bersifat konvensional, dimana siswa tampak pasif dan menerima pengetahuan sesuai dengan yang diberikan guru. 
Pada waktu guru memberi kesempatan untuk menjawab ataupun bertanya, siswa bingung apa yang akan dijawab dan ditanyakan. Hal ini merupakan indikasi bahwa kemampuan berpikir, pemahaman konsep fisika siswa masih tergolong rendah. Sehingga mengakibatkan hasil belajar fisika siswa itu rendah. Hal ini sesuai hasil observasi yang dilakukan penulis di SMA Negeri 20 Medan, ketika siswa diminta pendapat tentang pelajaran fisika, hanya beberapa orang yang berminat untuk belajar fisika sedangkan sebagian besar kurang berminat untuk mempelajarinya. Mereka menganggap pelajaran fisika merupakan pelajaran yang sulit dan membosankan. Terlalu banyak rumus sehingga menyulitkan siswa untuk mengingat rumus-rumus tersebut. Ketika guru bertanya kepada siswa apakah materi yang disampaikan guru tersebut bisa dimengerti, siswa hanya diam saja dengan kata lain tidak ada siswa yang memberikan jawaban yang pasti, ini sangat berpengaruh terhadap hasil belajar mereka.

Berbagai usaha telah dilakukan guru dalam mengatasi permasalahan tersebut, seperti melakukan diskusi dan tanya jawab. Tetapi usaha itu belum mampu merangsang siswa untuk aktif dalam pembelajaran, karena siswa yang menjawab pertanyaan guru cenderung didominasi oleh beberapa orang saja. Usaha lain yang dilakukan guru adalah dengan melaksanakan pembelajaran dalam setting kelompok kecil. Akan tetapi siswa lebih banyak bekerja sendirisendiri dalam menyelesaikan soalsoal yang diberikan guru.
Kenyataan ini menunjukkan bahwa usaha-usaha yang telah dilakukan guru tampaknya belum membuahkan hasil optimal dalam meningkatkan hasil belajar siswa. Disini penulis menawarkan sebuah model pembelajaran yaitu model pembelajaran berbasis masalah.

Sebelumnya penelitian menggunakan model pembelajaran berbasis masalah telah di teliti oleh Kenedy (2008) di SMA N 4 Kisaran pada materi pokok Pemuaian diperoleh nilai rata-rata pretes kelas eksperimen 30,66 setelah diberi perlakuan dengan model pembelajaran berbasis masalah maka hasil belajar fisika siswa meningkat dengan nilai rata-rata postes 68,66. Menurut hasil penelitian Sidabutar (2010) yang menerapkan model pembelajaran berbasis masalah di SMA N 1 Dolok Sanggul pada materi pokok Listrik Dinamis diperoleh nilai pretes kelas eksperimen 4,197 setelah dilakukan perlakuan dengan model pembelajaran berbasis masalah diperoleh hasil postes 7,54

Sehubungan dengan masalah di atas, maka peneliti tertarik untuk menggunakan model pembelajaran berbasis masalah dengan memperhitungkan waktu yang dibutuhkan untuk setiap langkah dan benar-benar dapat menyesuaikan alokasi waktu yang ada dengan rencana pembelajaran yang dibuat. Tujuan penelitian ini untuk mengetahui pengaruh model pembelajaran berbasis masalah terhadap hasil belajar siswa kelas X semester II pada materi pokok suhu dan kalor SMA Negeri 20 Medan T.P 2013/2014 


\section{METODE PENELITIAN}

Populasi penelitian ini adalah seluruh siswa SMA Negeri 20 Medan kelas X semester II berjumlah 5 kelas terdiri dari 165 orang tahun ajaran 2013/2014 . Sampel penelitian terdiri dari dua kelas yang mewakili populasi dengan mempunyai karakteristik yang sama, yang masing-masing kelas 33 siswa. Salah satu kelas sebagai kelas eksperimen dan satu kelas lain sebagai kelas kontrol. Teknik pengambilan sampel diambil secara acak dengan menggunakan Cluster Random Sampling.

Jenis penelitian ini adalah penelitian quasi eksperimen, yaitu penelitian yang bertujuan untuk mengetahui ada tidaknya pengaruh atau akibat dari sesuatu yang ditimbulkan pada subjek yaitu siswa. Sampel yang diambil dalam penelitian ini dibagi atas dua kelas yaitu kelas eksperimen dan kelas kontrol, kedua kelas ini mendapat perlakuan yang berbeda. Kelas eksperimen diberikan pembelajaran dengan model pembelajaran berbasis masalah sedangkan kelas kontrol diberikan dengan pembelajaran konvensional. Penelitian ini melibatkan dua kelas yang diberi perlakuan berbeda. Untuk mengetahui hasil belajar siswa dilakukan dengan memberikan tes pada kedua kelas sebelum dan sesudah diberi perlakuan. Rancangan penelitian quasi eksperimen ini dengan desain: control group pretest-postes design. Pre-tes digunakan untuk menyetarakan pengetahuan awal kedua kelompok sedangkan post-tes digunakan untuk mengukur penalaran atau pemahaman siswa setelah diberi perlakuan. Rancangan eksperimennya dapat dilihat dalam Tabel 1.

Tabel 1. Desain Penelitian tipe control group pretest-postes design

\begin{tabular}{|l|c|c|c|}
\hline Kelompok & $\begin{array}{c}\text { Pre } \\
\text { tes }\end{array}$ & $\begin{array}{c}\text { Treatme } \\
\text { nt }\end{array}$ & $\begin{array}{c}\text { Poste } \\
\mathrm{s}\end{array}$ \\
\hline Eksperimen & $\mathrm{O}_{1}$ & $\mathrm{X}_{1}$ & $\mathrm{O}_{2}$ \\
\hline Kontrol & $\mathrm{O}_{1}$ & $\mathrm{X}_{2}$ & $\mathrm{O}_{2}$ \\
\hline
\end{tabular}

Tipe soal adalah berbentuk essai, tes ini digunakan sebagai tes awal untuk melihat prior knowledge siswa dan tes akhir untuk mengetahui pengaruh model pembelajaran berbasis masalah terhadap hasil belajar siswa. Ranah kognitif yang diukur mengikuti taksonomi Bloom yang meliputi pengetahuan $\left(\mathrm{C}_{1}\right)$, pemahaman $\left(\mathrm{C}_{2}\right)$, aplikasi $\left(\mathrm{C}_{3}\right)$, analisis $\left(\mathrm{C}_{4}\right)$, evaluasi $\left(\mathrm{C}_{5}\right)$, dan mencipta $\left(\mathrm{C}_{6}\right)$.

Rancangan penelitian yang telah dilakukan melalui beberapa tahapan,yaitu sebagai berikut:

1. Tahap Persiapan

2. Tahap Pelaksanaan

3. Tahap Pengumpulan dan pengolahan Data

\section{HASIL PENELITIAN DAN PEMBAHASAN \\ Hasil Penelitian}

Hasil penelitian yang dilakukan untuk mengetahui hasil belajar siswa sebelum kedua sampel diterapkan perlakuan yang berbeda, yaitu kelas eksperimen diberi perlakuan dengan menggunakan model pembelajaran berbasis masalah dan kelas kontrol diberi perlakuan dengan menggunakan pembelajaran konvensional, Untuk melihat secara rinci hasil pretes dan postes kedua kelas dapat dilihat pada Gambar 1. dan Gambar 2. 


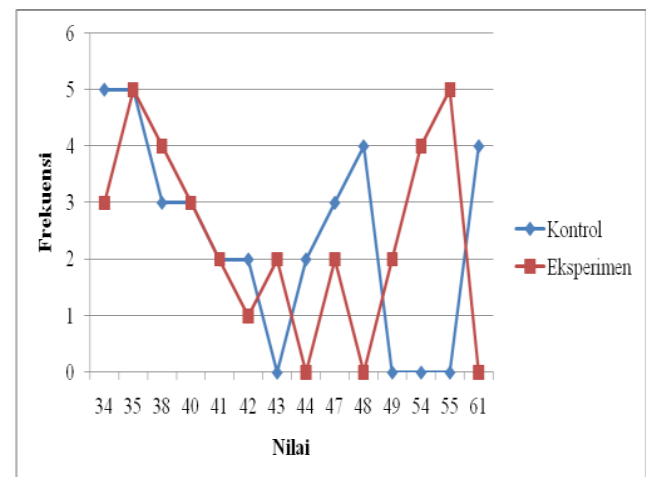

Gambar 1. Grafik data pretes kelas eksperimen dan kelas kontrol

Berdasarkan Gambar 1. dijelaskan bahwa hasil pretes antara kedua kelas tidak ada perbedaan yang signifikan yaitu pada kelas eksperimen diperoleh nilai rata-rata 43,69 dan pada kelas kontrol diperoleh nila 42,78. Hal ini dikarenakan kedua kelas memiliki kemampuan awal yang sama sebelum diberlakukannya perlakuan.

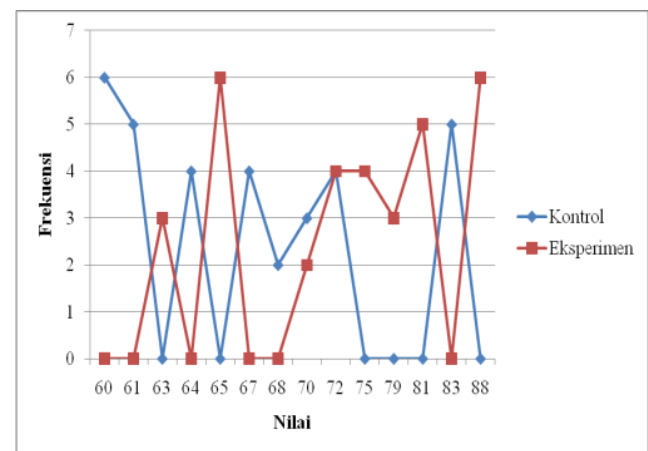

Gambar 2. Grafik Data Postes Kelas

Eksperimen Dan Kelas Kontrol

Beradasrkan Gambar 2. menjelaskan hasil setelah kedua sampel diterapkan perlakuan yang berbeda dimana pada kelas eksperimen diterapkan model pembelajaran pembelajaran berdasarkan masalah dan pada kelas kontrol diterapkan model pembelajaran konvensional diperoleh hasil postes kedua kelas memiliki nilai rata-rata yaitu pada kelas eksperimen 75,06 dan pada kelas kontrol 67,81. Terdapat perbedaan hasil belajar siswa yang signifikan yaitu pada kelas eksperimen lebih tinggi dibandingkan dengan kelas kontrol hal ini disebabkan karena adanya pengaruh perlakuan pada kedua kelas.

Sebelum dilakukan uji hipotesis terlebih dahulu dilakukan uji prasyarat data yaitu uji normalitas dengan menggunakan uji liliefors. Hasil uji normalitas yang diperoleh dapat dilihat pada Tabel 3.

Tabel 3. Uji Normalitas Data Pretes Kelas Eksperimen dan Kelas Kontrol

\begin{tabular}{|c|c|c|c|}
\hline \multirow{2}{*}{ Kelas } & \multicolumn{2}{|c|}{ Data Pretes } & Kesimpulan \\
\cline { 2 - 4 } & Lhitung & Ltabel & \\
\hline Eksperimen & 0,148 & 0,154 & Normal \\
\hline Kontrol & 0,152 & 0,154 & Normal \\
\hline
\end{tabular}

Berdasarkan Tabel 3, menjelaskan bahwa pada taraf signifikan $\alpha=0,05$ dan $\mathrm{n}=33$ diperoleh harga $L_{\text {wbel }}=0,154$ dengan demikian pada kelas eksperimen dan kontrol $\mathrm{L}_{\text {hitung }}<\mathrm{L}_{\text {tabel }}$ sehingga dapat disimpulkan bahwa data dari kedua kelas yaitu kelas eksperimen dan kelas kontrol berdistribusi normal.

Tabel 4. Uji Normalitas Data Postes Kelas Eksperimen dan Kelas Kontrol

\begin{tabular}{|c|c|c|c|}
\hline \multirow{2}{*}{ Kelas } & \multicolumn{2}{|c|}{ Data Postes } & Kesimpulan \\
\cline { 2 - 4 } Lhitung & Ltabel & \\
\hline Eksperimen & 0,151 & 0,154 & Normal \\
\hline Kontrol & 0,143 & 0,154 & Normal \\
\hline
\end{tabular}


Berdasarkan Tabel 4. bahwa L $_{\text {hitung }}<\mathrm{L}_{\text {tabel }}$ sehingga disimpulkan bahwa data dari kedua kelas berdistribusi normal.

Pengujian

homogenitas dilakukan untuk mengetahui apakah kelas sampel berasal dari populasi yang homogen atau tidak, artinya apakah sampel yang dipakai dalam penelitian ini dapat mewakili seluruh populasi yang ada.

Pengujian homogenitas data dilakukan dengan menhuji nila pretes kedua kelas dengan uji $\mathrm{F}$. Hasil uji homogenitas data yang diperoleh dapat dilihat pada Tabel 5.

Tabel 5. Ringkasan Hasil Uji Homogenitas Data

\begin{tabular}{|c|c|c|c|}
\hline Data & Varians & $\begin{array}{c}\mathrm{F}_{\text {hitu }} \\
\mathrm{ng}\end{array}$ & $\mathrm{F}_{\text {tabel }}$ \\
\cline { 1 - 2 } Eskperimen & 62,217 & 1,18 & $\begin{array}{c}1,80 \\
8\end{array}$ \\
\hline Kontrol & 73,466 & 0 & 8 \\
\hline
\end{tabular}

Beradsarkan Tabel 5, nilai $\mathrm{F}_{\text {hitung }}<\mathrm{F}_{\text {tabel }}$ yang berarti bahwa sampel yang digunakan dalam penelitian ini dinyatakan homogen atau dapat mewakili seluruh populasi yang ada.

Untuk pengujian hipotesis dilakukan pengujian nilai posttes dengan menggunakan uji $t$ yaitu membedakan rata-rata posttes siswa kelas eksperimen dan kontrol dengan tujuan untuk mengetahui ada tidaknya pengaruh model pembelajaran berbasis masalah terhadap hasil belajar siswa. Hasil pengujian hipotesis pada taraf signifikan $\mathrm{a}=0,05 \mathrm{dan} \mathrm{dk}=64$, untuk pengujian postes diperoleh $t_{\text {hitung }}=3,70$ sedangkan $t_{\text {tabel }}=1,669$.

Kriteria pengujian $t_{\text {hitung }}>t_{\text {tabel }}(3,70$ $>1,669)$, maka Ho di tolak dan $\mathrm{Ha}$ di terima dengan kata lain bahwa hasil belajar siswa pada kelas eksperimen lebih besar dari hasil belajar kelas kontrol, berarti Ada pengaruh Model Pembelajaran Berbasis Masalah terhadap hasil belajar siswa kelas $\mathrm{X}$ pada materi pokok suhu dan kalor semester II SMA Negeri 20 Medan T.P 2013/2014. Hasil pengujian hipotesis dapat dilihat pada Tabel 6 .

Tabel 6. Ringkasan Perhitungan Uji

\begin{tabular}{|c|c|c|c|}
\hline $\begin{array}{c}\text { Data } \\
\text { Postes }\end{array}$ & $\begin{array}{c}\text { Rata- } \\
\text { rata }\end{array}$ & $\begin{array}{c}\text { thitun }_{\text {g }} \\
\text { g tabel }\end{array}$ \\
\hline Eksperimen & 75,06 & \multirow{2}{*}{3,70} & 1,669 \\
\hline Kontrol & 67,81 & 3,70 & \\
\hline
\end{tabular}

\section{Observasi}

Observasi bertujuan untuk mengamati aktivitas belajar, sikap dan psikomotor siswa selama pembelajaran dengan model pembelajaran berbasis masalah dan pembelajaran konvensional. Observasi dilakukan dengan satu observer yaitu mahasiswa fisika sebagai pengamat dan pemberi nilai.

Perkembangan aktivitas belajar, sikap dan psikomotorik siswa di kelas eksperimen mengalami peningkatan selama menerima pembelajaran dengan menggunakan model pembelajaran berbasis masalah. Bahkan di kelas kontrolpun memiliki tingkat aktivitas dan sikap yang meningkat dari pertemuan I sampai pertemuan III, namun itu tidak sesignifikan kelas eksperimen.

Hal ini menunjukkan bahwa model pembelajaran berbasis masalah tidak hanya meningkatkan hasil belajar saja, tetapi juga mampu meningkatkan aktivitas, sikap dan psikomotor siswa. Ternyata aktivitas ini juga 
memiliki kontribusi yang cukup besar terhadap hasil belajar siswa yaitu dilihat dari peningkatan hasil belajar siswa dengan nilai rata-rata postes pada kelas eksperimen yang baik sebesar 75,06.

\section{Hasil}

penelitian

menunjukkan bahwa ada pengaruh menggunakan model pembelajaran berbasis masalah terhadap hasil belajar siswa kelas $\mathrm{X}$ semester II SMA Negeri 20 Medan pada materi pokok suhu dan kalor T.P 2013/2014. Untuk melihat secara rinci perkembangan aktivitas sikap dan psikomotorik siswa dapat dilihat pada gambar berikut:

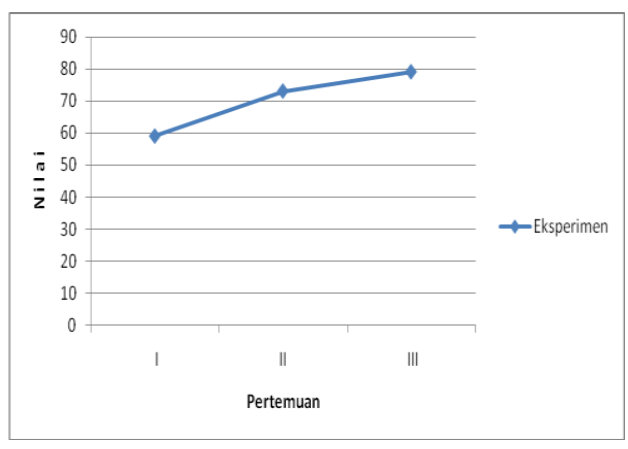

Gambar 3. Perkembangan Aktivitas Belajar Siswa

Berdasarkan

hasil pengamatan yang dilakukan oleh observer diperoleh bahwa aktivitas belajar siswa pada kelas eksperimen pada pertemuan I sebesar $59 \%$, ke II sebesar $73 \%$ dan ke III sebesar 79\%.

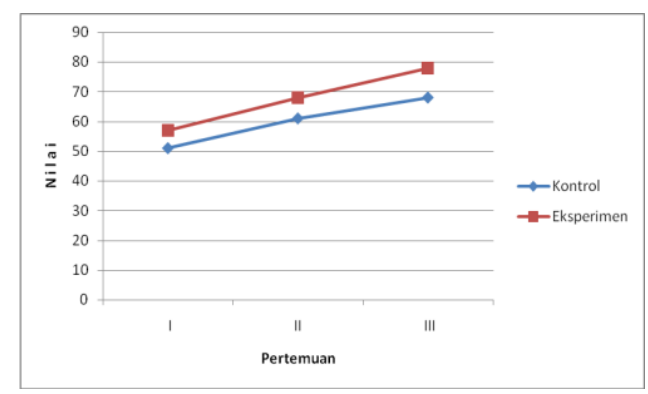

Gambar 4. Perkembangan Afektif Siswa
Pada nilai afektif siswa mengalami peningkatan yang positif. Pada pertemuan I rata-rata nila afektif siswa diperoleh sebesar 57\%. Hal ini terjadi karena siswa belum terbiasa dengan pembelajaran menggunakan model berbasis masalah. Oleh karena itu, peneliti terus memberikan instruksi dan arahan kepada siswa hingga siswa paham dan termotivasi dalam pembelajaran. Pada pertemuan II diperoleh peningkatan yang positif terhadap aktivitas siswa dengan nilai rata-rata $68 \%$ serta pada pertemuan III naik menjadi $78 \%$.

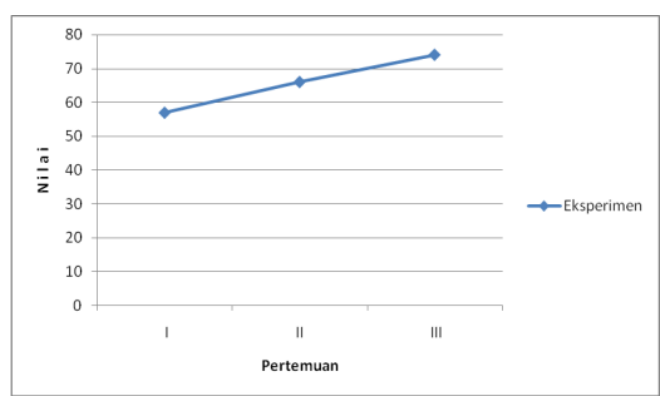

Gambar 5. Perkembangan Psikomotorik Siswa

Ternyata, aktivitas siswa yang dikategorikan aktif sejalan dengan peningkatan psikomotorik siswa yang juga dikategorikan baik yaitu pada pertemuan I diperoleh nilai rata-rata $57 \%$ dan pertemuan II $66 \%$ dan pertemuan III $74 \%$.

Hasil penelitian menunjukkan bahwa ada pengaruh menggunakan Pembelajaran Berbasis Masalah terhadap hasil belajar siswa kelas $\mathrm{X}$ semester II SMA Negeri 20 Medan pada materi pokok suhu dan kalor T.P 2013/2014. Hal ini diperkuat dengan perolehan nilai rata-rata pretes siswa di kelas eksperimen sebesar 43,696 dengan standar deviasi 7,887 dan nilai rata-rata postes sebesar 
75,06 dengan standar deviasi 8,587. Sedangkan di kelas kontrol diperoleh nilai rata-rata pretes siswa sebesar 42,781 dengan standar deviasi 8,571 dan nilai ratarata postes sebesar 67,818 dengan standar deviasi 7,699.

Selama

pelaksanaan penelitian diperoleh bahwa model pembelajaran berbasis masalah menguntungkan karena model ini memang didesain untuk mengajak siswa untuk berfikir secara individual dan kelompok untuk memecahkan masalah dalam situasi nyata, membangun pengetahuannya sendiri melalui aktivitas belajar. Model pembelajaran berfokus pada masalah sehingga materi yang tidak ada hubungannya tidak perlu saat itu dipelajari oleh siswa. Hal ini mengurangi beban siswa dengan menghafal atau menyimpan informasi.

Pada dasarnya, tujuan utama penelitian ini adalah untuk mengetahui pengaruh model pembelajaran berbasis masalah terhadap hasil belajar siswa. Namun, peneliti juga ingin melihat dan menilai bagaimana aktivitas siswa selama dilaksanakan model pembelajaran berbasis masalah, maka perlu dilakukan pencatatan terhadap aktivitas siswa selama kegiatan pembelajaran berlangsung.

Dari hasil pengamatan yang dilakukan oleh observer diperoleh bahwa aktivitas belajar siswa pada kelas eksperimen pada pertemuan I sebesar 59\%, ke II sebesar 73\% dan ke III sebesar 79\%. Pada nilai afektif siswa mengalami peningkatan yang positif. Pada pertemuan I rata-rata nila afektif siswa diperoleh sebesar 57\%. Hal ini terjadi karena siswa belum terbiasa dengan pembelajaran menggunakan model berbasis masalah. Oleh karena itu, peneliti terus memberikan instruksi dan arahan kepada siswa hingga siswa paham dan termotivasi dalam pembelajaran. Pada pertemuan II diperoleh peningkatan yang positif terhadap aktivitas siswa dengan nilai rata-rata $68 \%$ serta pada pertemuan III naik menjadi $78 \%$. Hal ini karena siswa sudah mulai memahami tugas mereka dan tanggung jawab mereka dalam pembelajaran ini, dimana peneliti terus memberikan motivasi dan arahan kepada siswa. Dan dari peningkatan ini maka dapat disimpulkan siswa aktif dalam materi ini. Ternyata, aktivitas siswa yang dikategorikan aktif sejalan dengan peningkatan psikomotorik siswa yang juga dikategorikan baik yaitu pada pertemuan I diperoleh nilai rata-rata $57 \%$ dan pertemuan II $66 \%$ dan pertemuan III $74 \%$.

Walaupun penggunaan model pembelajaran berbasis masalah ini dapat meningkatkan hasil belajar dan aktivitas siswa, tetapi selama pembelajaran masih ada kendala yang dihadapi, yaitu masih ada siswa yang kurang tertarik dengan model pembelajaran berbasis masalah ini karena telah terbiasa untuk belajar menggunakan pembelajaran konvensional yang identik dengan ceramah. Oleh sebab itu, upaya yang dilakukan adalah dengan membuat pembelajaran menjadi lebih menarik,

\section{KESIMPULAN DAN SARAN}

Berdasarkan hasil penelitian yang diperoleh maka dapat disimpulkan bahwa: nilai rata - rata siswa dengan menggunakan model pembelajaran berbasis masalah 
pada materi suhu dan kalor adalah 75,06. Nilai rata - rata siswa dengan menggunakan pembelajaran konvensional pada materi suhu dan kalor adalah 67,81.

Aktivitas belajar siswa yang diajar dengan menerapkan model pembelajaran berbasis masalah mengalami peningkatan dengan nilai rata-rata afektif di kelas eksperimen pada pertemuan pertama sebesar $57 \%$, pertemuan kedua $68 \%$ dan pertemuan ketiga sebesar 78\%. Aktivitas belajar siswa yang diajar dengan menerapkan pembelajaran konvensional mengalami peningkatan dengan nilai rata-rata afektif di kelas kontrol pada pertemuan pertama sebesar 51\%, pertemuan kedua $61 \%$ dan pertemuan ketiga sebesar $68 \%$. Ada pengaruh Model Pembelajaran Berbasis Masalah terhadap hasil belajar siswa kelas $\mathrm{X}$ pada materi pokok suhu dan kalor semester dua SMA Negeri dua puluh Medan.

Saran yang dapat peneliti ajukan berdasarkan pembahasan adalah sebagai berikut:

Untuk peneliti selanjutnya diharapkan lebih mengoptimalkan pengelolaan kelas khususnya pada saat diskusi berlangsung agar tidak terjadi kegaduhan-kegaduhan di dalam kelas; Kepada peneliti selanjutnya yang ingin meneliti tentang model pembelajaran berdasarkan masalah, ada baiknya memberikan motivasi terlebih dahulu kepada siswa yang akan mempresentasikan hasil karya untuk meningkatkan rasa percaya diri pada siswa tersebut; Kepada peneliti selanjutnya yang ingin meneliti tentang model pembelajaran berbasis masalah, karena aktivitas yang akan diobservasi banyak maka supaya efektif diperlukan satu observer setiap kelompok.

\section{DAFTAR PUSTAKA}

Arends, R. I. , (2008), Learning to Teach Edisi Ketujuh, Pustaka Pelajar, Yogyakarta.

Arikunto, S., (2011) , Dasar-Dasar Evaluasi Penelitian, Bumi Aksara, Jakarta.

Arikunto, S., (2006), Prosedur Penelitian Suatu Pendekatan Praktik, Penerbit Bumi Aksara, Jakarta.

Fahchrurazi, (2011), Penerapan Pembelajaran Berbasis

Masalah Untuk

Meningkatkan Kemampuan Berpikir Kritis Dan Komunikasi Matematis Siswa Sekolah Dasar, Jurnal FMIPA UPI, Vol.9, No.8, 2011.

Fakultas Matematika dan Ilmu Pengetahuan Alam Universitas Negeri Medan. (2012), Buku Pedoman Penulisan Proposal dan Skripsi Mahasiswa Program Studi Pendidikan FMIPA Unimed, FMIPA Unimed, Medan.

Haratua, Fitria, Tomo, R., (2013), Penggunaan Model Problem Based Learning Dengan Multipresentasi Pada Usaha Dan Energi Di SMA, Jurnal FMIPA ITB, Vol.4, No.3, 2013., [05 maret 2014].

Kenedy, (2008), Pengaruh Model Pembelajaran Berbasis Masalah Terhadap Hasil Belajar Siswa Pada Materi Pemuaian di Kelas $X$ semester 2 SMA Negeri 4 Kisaran T.A 2007/2008.,Skripsi, FMIPA, Unimed, Medan. 
Kunandar, (2009), Guru Profesional, Rajawali Pers, Jakarta.

Mahmudi, K., (2013), Penerapan Lesson Study Menggunakan Model PBL ( Problem Based Learning) Dalam Pembelajaran Fisika, Jurnal FMIPA Universitas Jember, Vol.1, No.4, 2013, [05 maret 2014].

Suci, N.M., (2008), Penerapan Model Problem Based Learning Untuk Meningkatkan Partisipasi Belajar Dan Hasil Belajar Teori Akuntansi Mahasiswa Jurusan Ekonomi Undiksha, Jurnal FE Undiksha, Vol.2, No.1, 2008., [01 februari 2014].

Rusman, (2010) , Model Model Pembelajaran

Mengembangkan

Profesionalisme Guru, PT Raja Grafindo Persada, Jakarta.

Slameto, (2010), Belajar dan Faktorfaktor Yang Mempengaruhinya, Rineka Cipta, Jakarta.

Sardiman, (1986), Interaksi dan Motivasi Belajar Mengajar, PT Raja Grafindo Persada, Jakarta.

Sidabutar, P., (2010), Pengaruh Model Pembelajaran Berbasis Masalah Terhadap Hasil Belajar Siswa Pada Materi Pokok Listrik Dinamis di Kelas X Semester II SMAN 1 Dolok Sanggul T.P 2009/2010, Skripsi, FMIPA, Unimed, Medan.

Sudjana, (2005), Metode Statistika, Penerbit Tarsito, Bandung.

Sudjana, N., (2009), Penilaian Hasil Proses Belajar Mengajar,
PT. Remaja Rosdakarya, Bandung.

Tarigan, R., Derlina., (2011), Strategi Belajar Mengajar, FMIPA Unimed, Medan.

Wardani, K., Sunarno, Wida, S., (2012), Pembelajaran Fisika Berbasis Dengan Model Problem Based Learning Menggunakan Multimedia Dan Modul Ditinjau dari Kemampuan Berpikir Abstrak Dan Kemampuan Verbal, Jurnal FKIP Untan, Vol 1 No.2, 2012., [15 Maret 2014]. 